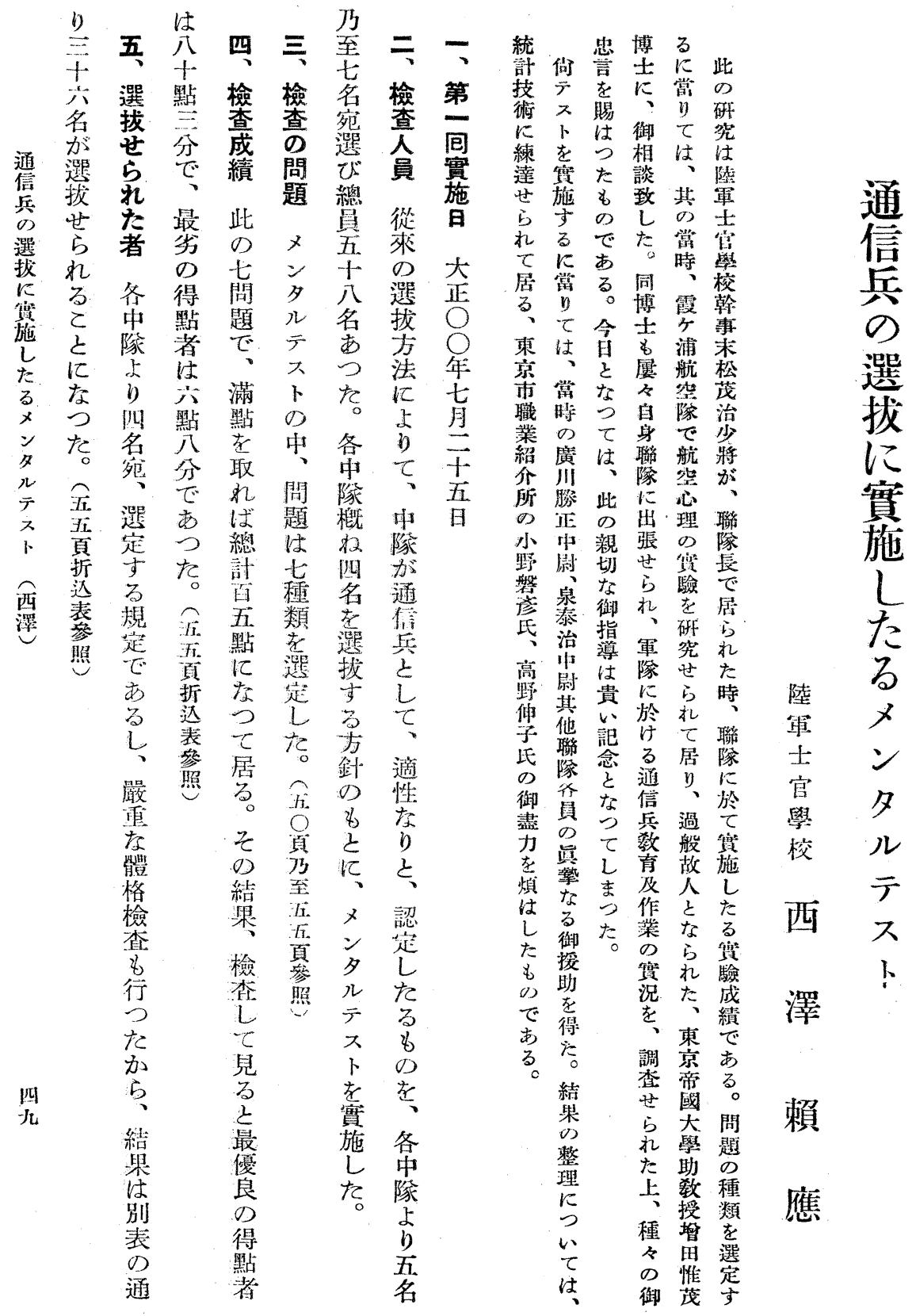




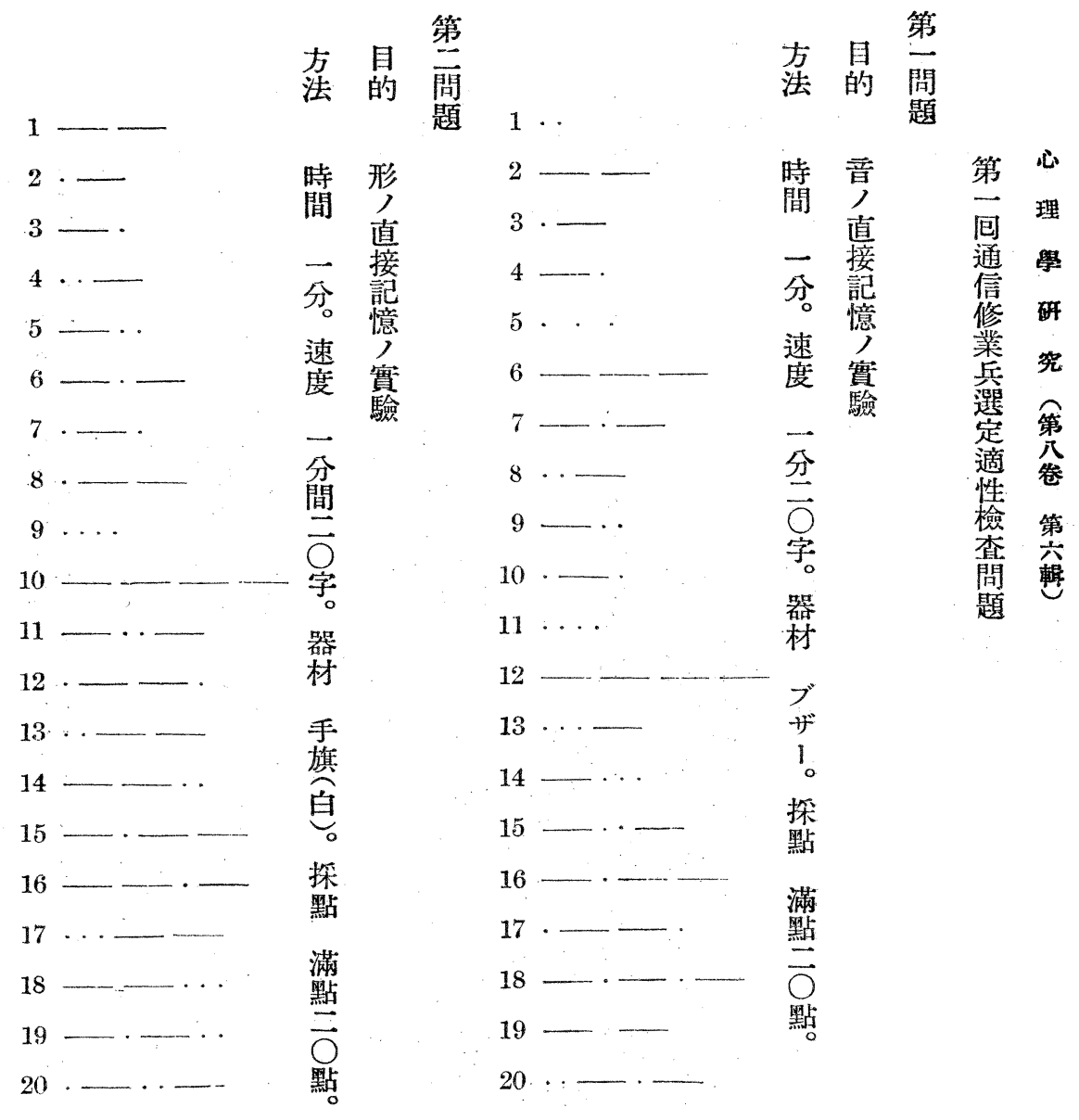

五 
893

$\begin{array}{cc} & \text { 第 } \\ \text { 目 } \\ \text { 的 問 } \\ \text { 題 }\end{array}$

方目 第

法的 問

例 ア行とカ行を書け

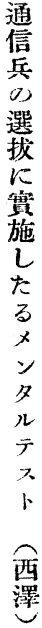

アイウエオカキクケコ

時 書

間 キ

單

$r$

赛 直

し 接

る 記

實

驗
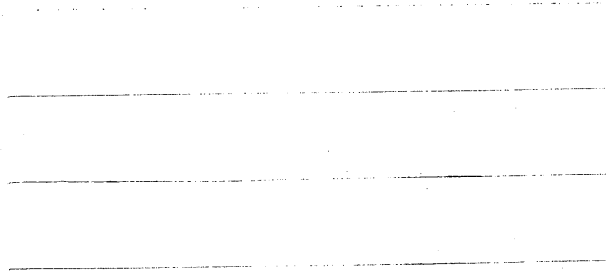

0

採

點

䒽

點

點

分 速

、實

₹ 驗

7

暗

シ

公 

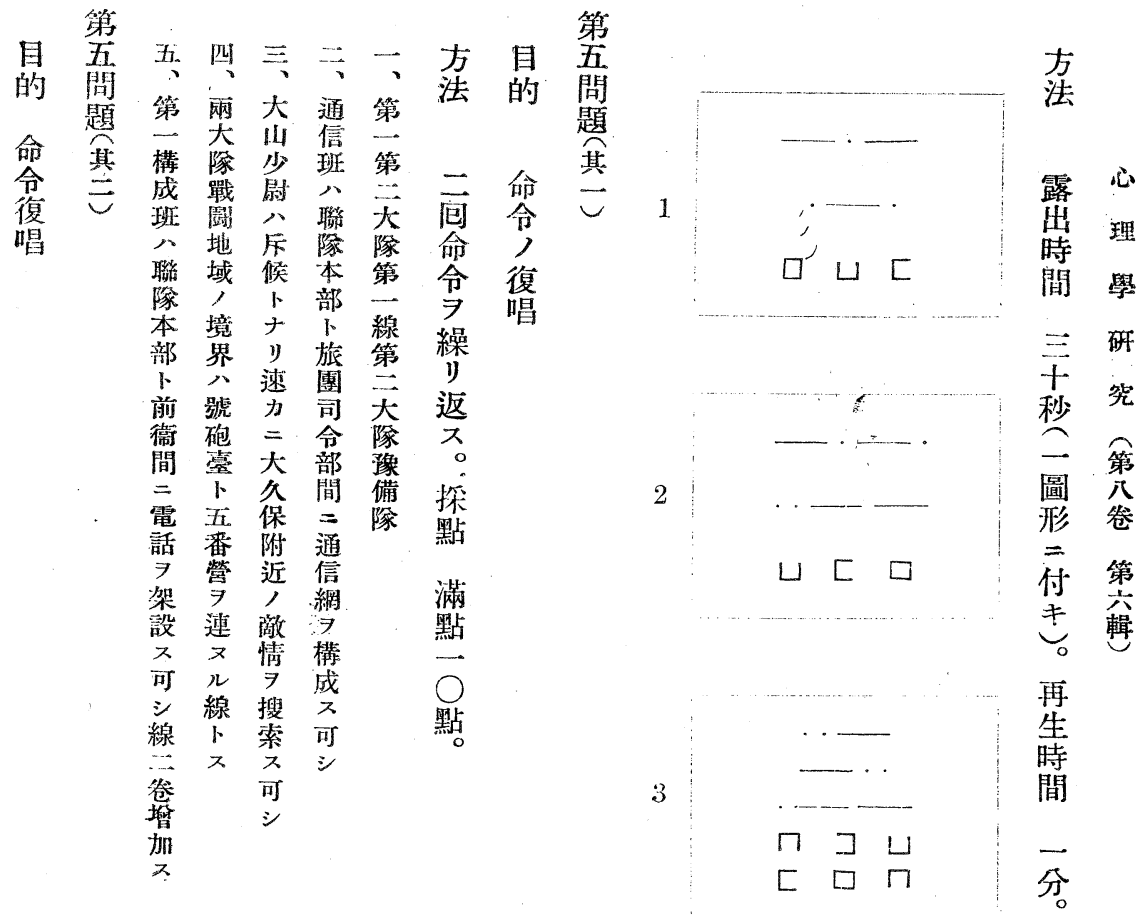

再
生
間
分

探

點

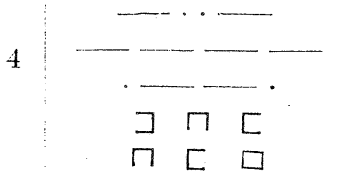

满
點
點
梷

別

\&

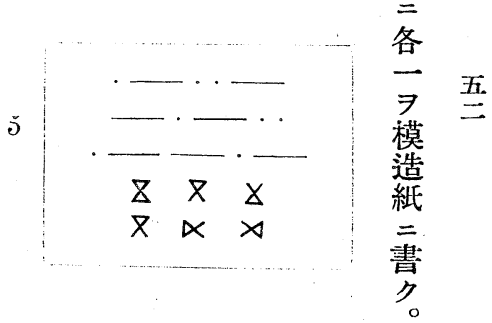




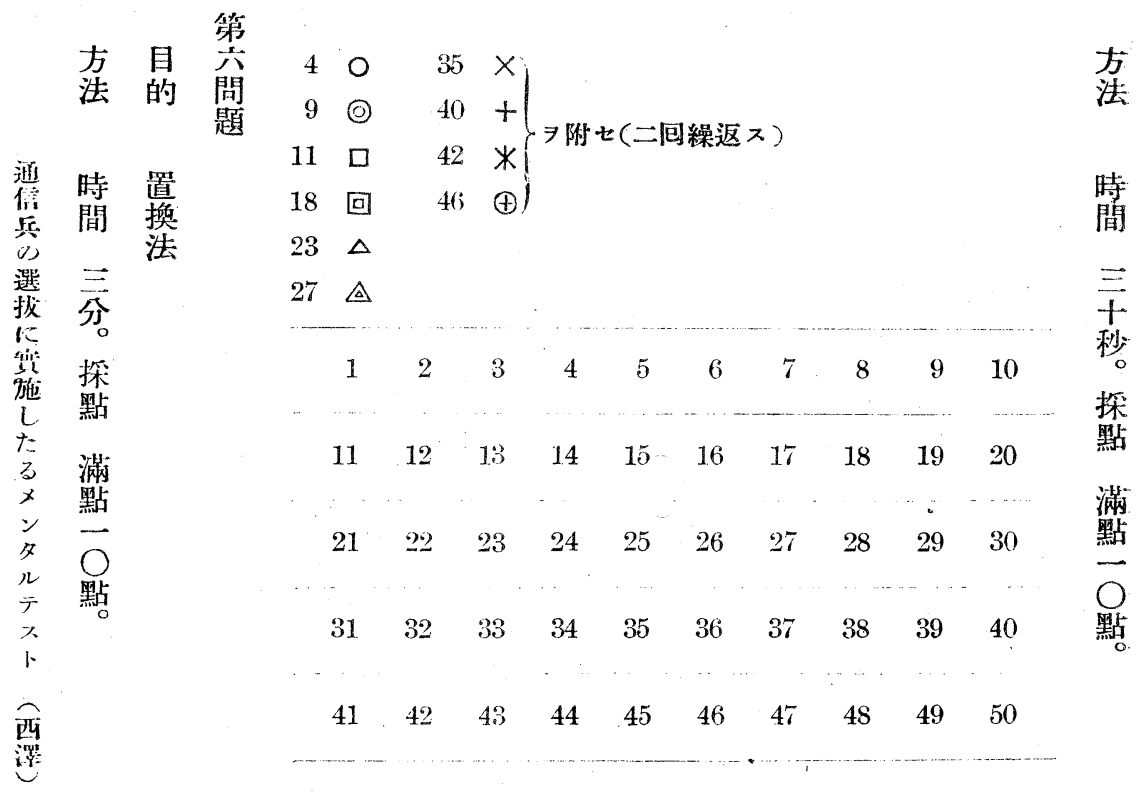

五. 


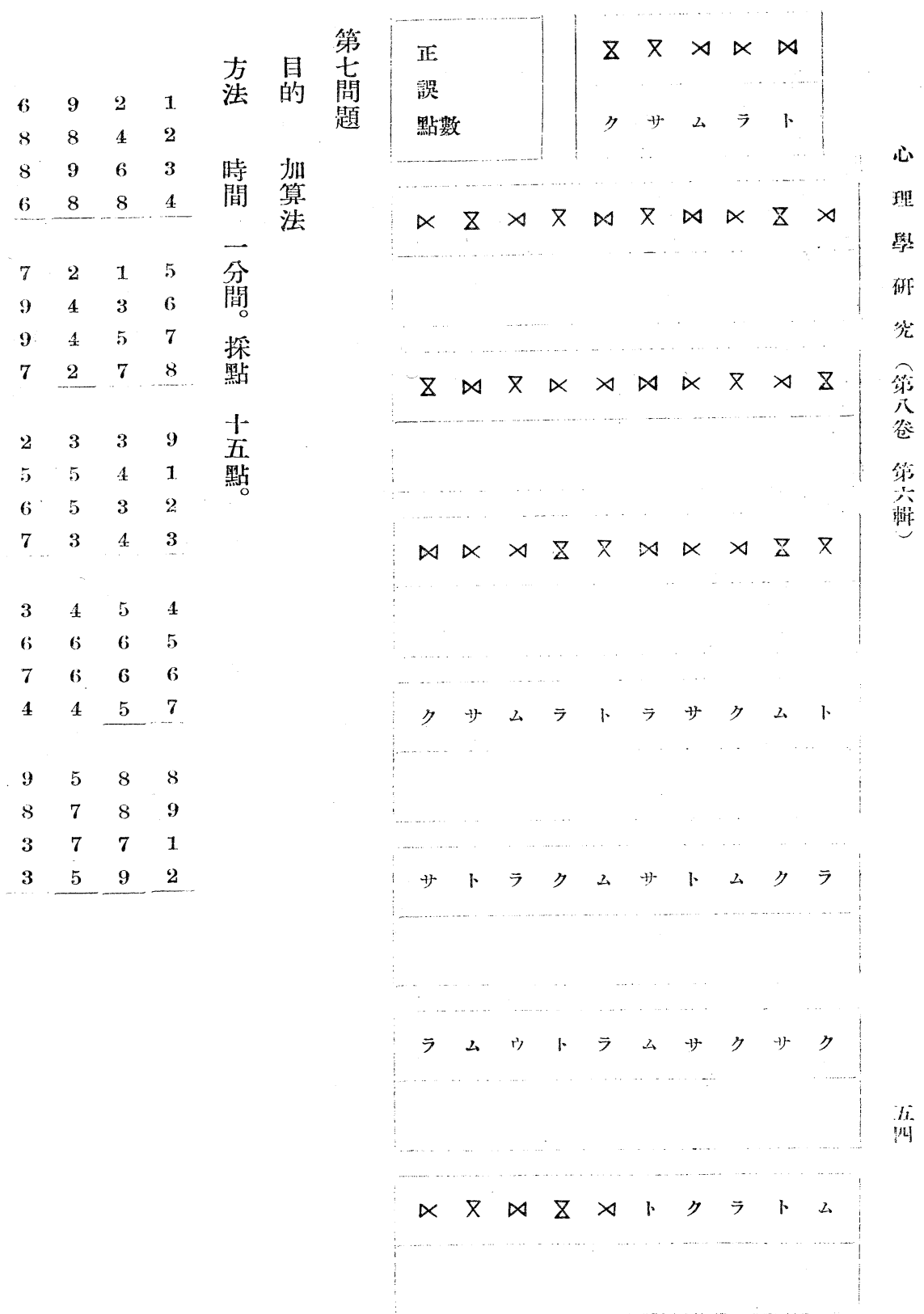




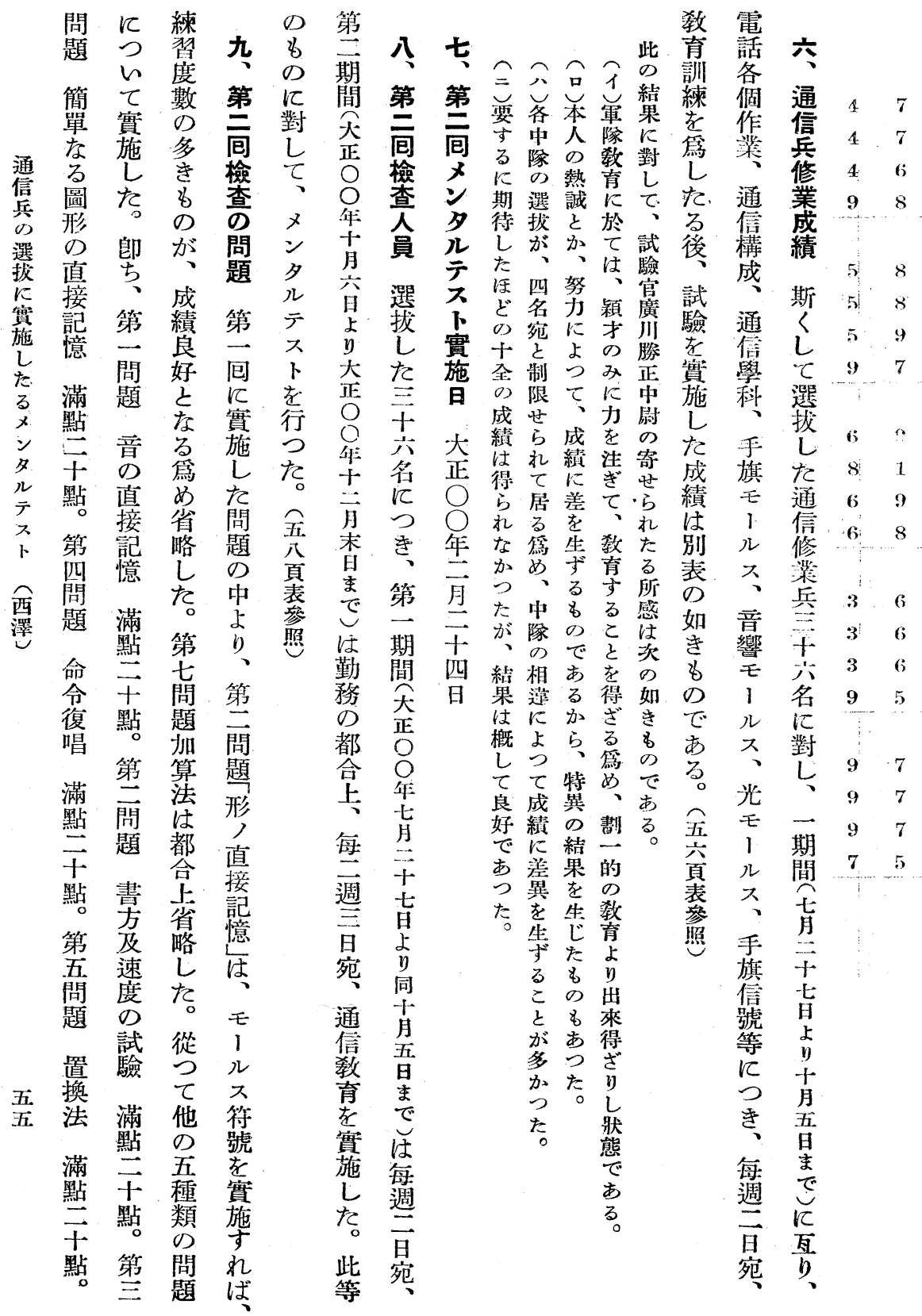


通信修鉴兵成績表

\begin{tabular}{|c|c|c|c|c|c|c|c|c|c|c|c|c|}
\hline $\begin{array}{c}\text { 第受 } \\
\text { 一檢 } \\
\text { 回號 } \\
\end{array}$ & 氏 & $\begin{array}{l}\text { 中 } \\
\text { 隊 } \\
\text { 號 }\end{array}$ & 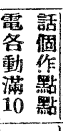 & 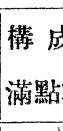 & & $\begin{array}{l}\text { 學科 } \\
\text { 淽點點 } \\
100 \\
\text { 啙 }\end{array}$ & $\begin{array}{c}\text { 手旗无 } \\
-\sim 2 \\
\text { 滿點 } \\
40 \text { 點 }\end{array}$ & $\begin{array}{l}\text { 音㢣王 } \\
\text { ル } \\
\text { 滿點 } \\
20 \text { 點 }\end{array}$ & $\begin{array}{l}\text { 光モ - } \\
\text { ル } \\
\text { 滿點 } \\
20 \text { 點 }\end{array}$ & $\begin{array}{l}\text { 手旗 } \\
\text { 信號 } \\
\text { 滿點 } \\
20 \text { 點 }\end{array}$ & $\begin{array}{l}\text { 合計 } \\
230 \text { 點 }\end{array}$ & 成績 \\
\hline 1 & 岡 $\bigcirc$ 鐵 藏 & 1 & 8 & 7 & 9 & 79 & 36 & 19.5 & 20 & 16 & $194 . \overline{0}$ & 3 \\
\hline 2 & ○原時 & 1 & 8 & 7 & 9 & 42 & 36.3 & 17.5 & 18.5 & 19.0 & 156.3 & 15 \\
\hline 3 & 井 $\bigcirc$ 八 作 & 1 & 6 & 7 & 7 & 50 & 11 & 10.5 & 10 & 10 & 111.5 & 32 \\
\hline 4 & ○中数二郎 & 1 & 8 & 7 & 7 & 40 & 34.7 & 15.0 & 10.5 & 17 & 139.2 & 24 \\
\hline 6 & ○島勇藏 & 2 & 6 & 7 & 9 & 38 & 14.9 & 10.2 & 8 & 8 & 101.1 & 34 \\
\hline 8 & ○井 五 郎 & 2 & 7.5 & 7.5 & 8 & 38 & 28 & 10.5 & 12 & 16 & 127.5 & 29 \\
\hline 9 & 菊 ○信一 & 2 & 6 & 7 & 6 & 38 & 29.1 & 10.3 & 13.5 & 13 & 122.9 & 30 \\
\hline 10 & ○田一男 & 2 & 6 & 7 & 3 & 42 & 37.9 & 19.4 & 19.8 & 20 & 155.1 & 17 \\
\hline 12 & ○澤與九郎 & 3 & 7.5 & 6 & 6 & 29 & 34 & 20 & 20 & 12 & 134.5 & 28 \\
\hline 13 & 瓣 $\bigcirc$ 光 雄 & 3 & 8 & 7 & 8 & 33 & 38.4 & 18.2 & 19.9 & 19.0 & 151.5 & 20 \\
\hline 14 & ○伯 辰 雄 & 3 & 8 & 7 & 8 & 42 & 35.1 & 19.2 & 19.9 & 16 & 155.2 & 16 \\
\hline 15 & 田 $\bigcirc$ 文藏 & 3 & 8 & 7 & 7 & 62 & 33.8 & 16.5 & 16.5 & 16 & 166.8 & 12 \\
\hline 19 & 淵 $\bigcirc$ 夈次 & 5 & 6 & 8 & 7 & 75 & 39.8 & 19.9 & 20 & 20 & 195.7 & 2 \\
\hline 20 & ○杢辰 雄 & 5 & 6 & 9 & 6 & 45 & 35.9 & 16.5 & 17 . & 19 & 154.4 & 19 \\
\hline 21 & 町 $\bigcirc$ 竹太郎 & 5 & 7.5 & 7 & 9 & 83 & 36.6 & 19.5 & 20 & 18 & 200.6 & 1 \\
\hline 22 & ○宮定 治 & 5 & 7 & 7 & 7 & 33 & 86.8 & 16.5 & 15 & 20 & 142.3 & 22 \\
\hline 26 & $\bigcirc$ 部 些 & 6 & 7.5 & 7 & 9 & 67 & 36.1 & 19.5 & 19.9 & 18 & 183.4 & 5 \\
\hline 27 & 西 ○揵太郎 & 6 & 7.5 & 7 & 7 & 30 & 39.3 & 19.7 & 20 & 20 & 150.5 & 21 \\
\hline 28 & ○井富二郎 & 6 & 7 & 7 & 4 & 70 & 33.3 & 11.3 & 1.5 & 10 & 167.6 & 11 \\
\hline 29 & 大 $\bigcirc$ 元 市 & 6 & 7 & 6.5 & 6 & 17 & 24.5 & 6.5 & 7.5 & 16 & 91.0 & 35 \\
\hline 33 & 都○繁太郎 & 7 & 7.5 & 8 & 6 & 40 & 34.3 & 13.5 & 19.5 & 11 & 139.8 & 23 \\
\hline 34 & ○ 村 政 雄 & 7 & 6 & 8 & 9 & 50 & 33 & 19.5 & 11.0 & 18 & 154.5 & 18 \\
\hline 35 & 椱 ○鎮太郎 & 7 & 7 & 6.5 & 8 & 39 & 29.3 & 17.3 & 17.5 & 14 & 138.6 & 25 \\
\hline 36 & ○崎读太郎 & 7 & 7.5 & 7 & 8 & 55 & 36 & 9.3 & 1 & 14 & 137.8 & 26 \\
\hline 40 & ○林福三郎 & 9 & 7.5 & 6.5 & 7 & 64 & 36.5 & 18.5 & 19.9 & 17 & 176.9 & 9 \\
\hline 41 & 飯 $\bigcirc$ 進吉 & 9 & 7.5 & 7.5 & 6 & 74 & 25.2 & 17.3 & 14.4 & 14 & 165.9 & 13 \\
\hline 42 & ○輪 昭 政 & 9 & 5 & 6 & 6 & 42 & 12.8 & 7 & 0 & 2 & 80.8 & 36 \\
\hline 43 & 墭 $\bigcirc$ 秀 雄 & 9 & 7.5 & 6 & 7 & 77 & 32.5 & 10.5 & 9 & 20 & 169.5 & 10 \\
\hline 46 & ○座宗義 & 10 & 7.5 & 6.5 & 8 & 70 & 36.1 & 19.2 & 19 & 18 & 184.3 & 4 \\
\hline 47 & 川○㦈一郎 & 10 & 5 & 6 & 9 & 60 & 37.9 & 19.2 & 20 & 20 & 177.1 & 8 \\
\hline 48 & $\bigcirc$ 井宗助 & 10 & 8 & 6.5 & 9 & 67 & 31.5 & 13 & 9 & 17 & 161.0 & 14 \\
\hline 49 & 村 ○義太郎 & 10 & 7 & 5 & 5 & 50 & 29.5 & 15.5 & 14 & 10 & 136.0 & 27 \\
\hline 52 & ○末頑一郎 & 11 & 7.5 & 7 & 6 & 86 & 34.9 & 14 & 8.5 & 19 & 182.9 & 6 \\
\hline 53 & 川 ○鉦太郎 & 11 & 8 & 6 & 6 & 80 & 33.7 & 14.6 & 10 & 19 & 177.2 & 7 \\
\hline 54 & $\bigcirc$ 藤 錤 助 & 11 & 7 & 6 & 9 & 30 & 30.8 & 5 & 5 & 18 & 110.8 & 33 \\
\hline 56 & ○原繁藏 & 11 & 7 & 6.5 & 4 & 38 & 28.5 & 13.2 & 13 & 12 & $12 \div .5$ & 30 \\
\hline
\end{tabular}




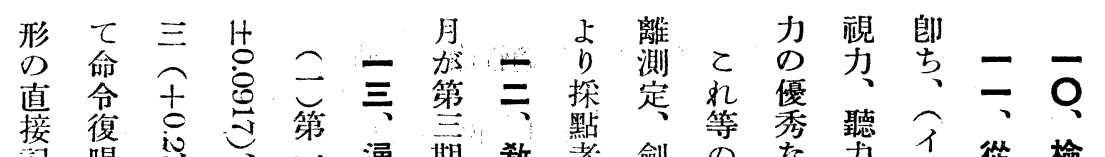

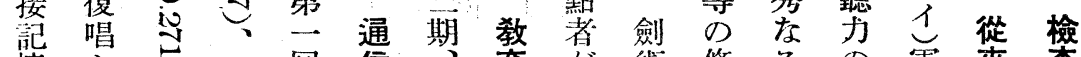
通憶占

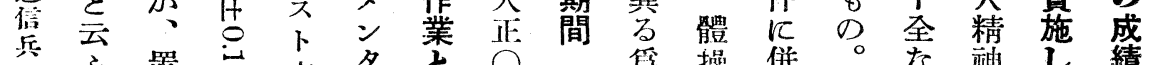

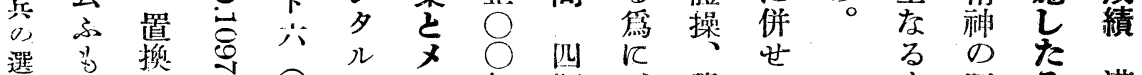

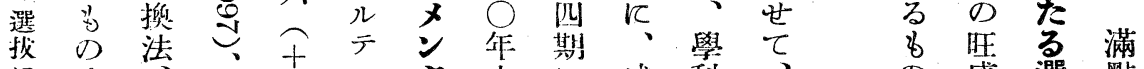

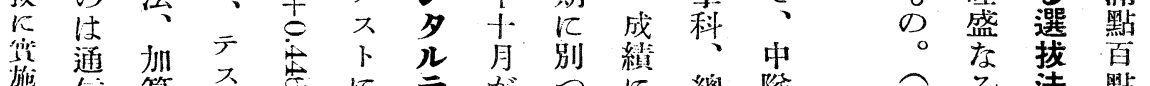
作 住

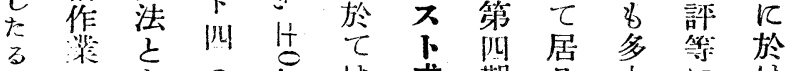

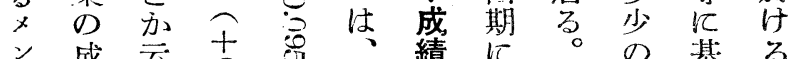

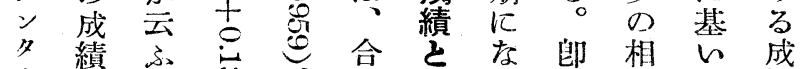

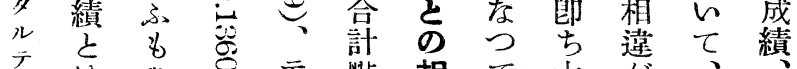
只相 が

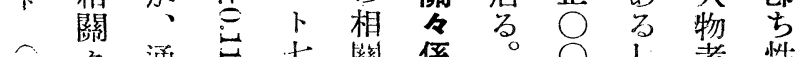

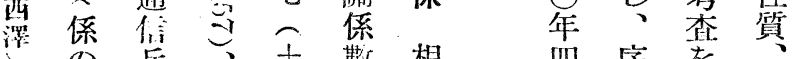

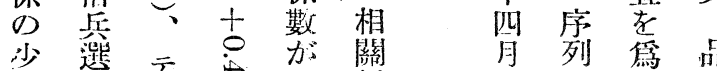

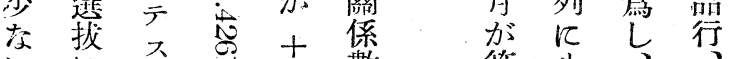
$\checkmark$ に 性關 質 係 \& 多 $! 00$ 诘

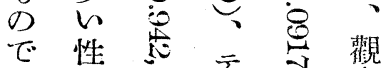
而質 る 兵可- 可罗

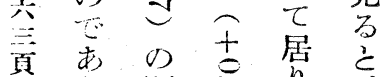

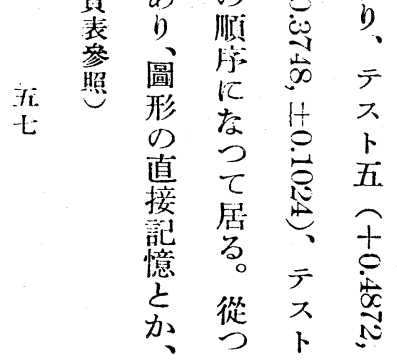
第名 - 多選 軆

期少拢格 穴美布勤 大兾方務 正老名品 ○告思栄 年疗市

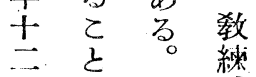
首务五緗 加击哲隽 第多鿓令

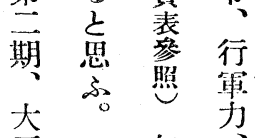
正

8 論 虫警

余多法點

㩽只通中 機優兵最 敏秀老優 古䅖選良 万拔者 क \& क 木 ○。名九 气義䈏·忢 三敄曾點 理垫 $\tau$, 蟹。生最 甚勥從劣

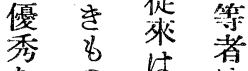
考。装意 委合金 名骂㕵 。尊條繁

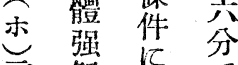
言强基分 語基要

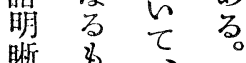
橗名 考蚉 多體隊 。㗊点

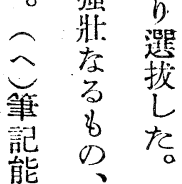


第二包通信修菜兵適性檢査成績表

\begin{tabular}{|c|c|c|c|c|c|c|c|c|c|c|c|}
\hline $\begin{array}{l}\text { 第受 } \\
\text { 一驗 } \\
\text { 國 } \\
\end{array}$ & 氏 & $\frac{\text { 第總 }}{\text { 包默 }}$ & $\frac{\text { 第序 }}{\text { 包列 }}$ & $\begin{array}{l}\text { 第問 } \\
\text { 一題 }\end{array}$ & $\begin{array}{l}\text { 第闁 } \\
\text { 二題 }\end{array}$ & $\begin{array}{l}\text { 第問 } \\
\text { 三題 }\end{array}$ & $\begin{array}{l}\text { 第闁 } \\
\text { 四題 }\end{array}$ & $\begin{array}{l}\text { 第問 } \\
\text { 五. 題 }\end{array}$ & $\begin{array}{l}\text { 第總 } \\
\text { 匈點 }\end{array}$ & $\begin{array}{l}\text { 序 } \\
\text { 列 }\end{array}$ & $\mid \begin{array}{l}\text { 通序 } \\
\text { 信列 }\end{array}$ \\
\hline 1 & 岡 $\bigcirc$ 鐵 藏 & 58.7 & 16 & 19.2 & 13.0 & 19.0 & 20.0 & 18.0 & 89.2 & 6 & 3 \\
\hline 2 & $\bigcirc$ 原 時 & 47.8 & 25 & 17.4 & 12.0 & 18.2 & 12.4 & 18.0 & 78.0 & 15 & 15 \\
\hline 3 & 井 $\bigcirc$ 八 作 & 42.7 & 29 & 4.0 & 3.0 & 12.6 & 6.8 & 16.0 & 42.4 & 35 & 32 \\
\hline 4 & ○中紋…… 郎 & 24.2 & 36 & 12.0 & 10.0 & 13.0 & 8.8 & 15.0 & 58.8 & 28 & 24 \\
\hline 6 & ○岛勇藏 & 50.9 & 23 & 0 & 10.0 & 18.8 & 10.6 & 19.0 & 58.4 & 29 & 34 \\
\hline 8 & ○井五 郎 & 36.3 & 30 & 18.0 & 10.0 & 16.4 & 10.8 & 18.0 & 73.2 & 21 & 29 \\
\hline 9 & 获 ○信一 & 32.6 & 32 & 12.0 & 7.0 & 15.2 & 12.2 & 10.0 & 56.4 & 32 & 30 \\
\hline 10 & ○田一男 & 26.4 & 35 & 5.2 & 4.0 & 16.4 & 6.0 & 8.0 & 39.6 & 36 & 17 \\
\hline 12 & ○澴與九 郎 & 64.5 & 4 & 19.2 & 10.0 & 17.8 & 18.4 & 10.0 & 75.4 & $16^{\circ}$ & 28 \\
\hline 13 & 棌 $\bigcirc$ 光 雄 & 61.8 & 9 & 19.2 & 11.0 & 18.0 & 14.0 & 16.0 & 78.2 & 14 & 20 \\
\hline 14 & ○伯 辰 雄 & 57.9 & 17 & 18.0 & 7.0 & 15.6 & 8.8 & 14.0 & 58.8 & 27 & 16 \\
\hline 15 & 田 ○文 藏 & 55.0 & 18 & 20.0 & 14.0 & 18.8 & 13.4 & 17.0 & 80.4 & 11 & 12 \\
\hline 19 & 淵 $\bigcirc$ 宗次 & 80.3 & 1 & 20.0 & 19.0 & 18.6 & 17.8 & 17.0 & 92.4 & 3 & 2 \\
\hline 20 & ○末㾁雄 & 62.8 & 6 & 18.0 & 18.0 & 19.2 & 19.6 & 19.6 & 84.4 & 8 & 19 \\
\hline 21 & 町 $\bigcirc$ 竹太郎 & 60.5 & 10 & 12.8 & 16.0 & 18.6 & 18.0 & 18.0 & 89.4 & 5 & 1 \\
\hline 22 & ○宮定 治 & 59.8 & 13 & 20.0 & 14.0 & 17.4 & 10.8 & 19.0 & 81.2 & 10 & 22 \\
\hline 26 & $\bigcirc$ 部 豐 & 72.3 & 2 & 18.6 & 20.0 & 17.0 & 17.6 & 19.6 & 92.8 & 2 & 5 \\
\hline 27 & 西 ○正太郎 & 62.9 & 5 & 17.4 & 14.0 & 20.0 & 15.4 & 20.0 & 86.8 & 7 & 21 \\
\hline 28 & ○井富二郎 & 43.9 & 28 & 19.2 & 14.0 & 17.2 & 6.8 & 16.0 & 73.2 & 20 & 11 \\
\hline 29 & 大 $\bigcirc$ 元 市 & 31.1 & 34 & 17.4 & 8.0 & 15.6 & 1.0 & 13.0 & 55.0 & 33 & 35 \\
\hline 33 & 都○繁太郎 & 63.2 & 7 & 16.0 & 11.0 & 17.6 & 10.0 & 19.0 & 73.6 & 19 & 23 \\
\hline 34 & ○村 政 雄 & 59.9 & 12 & 17.4 & 11.0 & 11.8 & 10.0 & 13.0 & 78.2 & 13 & 18 \\
\hline 35 & 榎 $\bigcirc$ 錤太郎 & 52.5 & 19 & 8.6 & 7.0 & 19.0 & 11.0 & 15.0 & 60.6 & 24 & 25 \\
\hline $36^{\circ}$ & ○崎涬太郎 & 44.1 & 27 & 15.2 & 11.0 & 18.6 & 14.8 & 8.0 & 67.6 & 22 & 26 \\
\hline 40 & $\bigcirc$ 林 福三郎 & 51.9 & 20 & 18.0 & 20.0 & 20.0 & 8.8 & 12.0 & 78.8 & 12 & 9 \\
\hline 41 & 飯 $\bigcirc$ 進 吉 & 48.7 & 24 & 15.2 & 15.0 & 15.6 & 11.0 & 10.0 & 66.8 & 23 & 13 \\
\hline 42 & $\bigcirc$ 輪 昭 政 & 47.5 & 26 & 9.2 & 9.0 & 16.0 & 13.8 & 6.0 & 54.0 & 34 & 36 \\
\hline .43 & 鹽 ○秀 雄 & 34.6 & 31 & 8.0 & 7.0 & 17.4 & 10.2 & 17.0 & 59.6 & 25 & 10 \\
\hline 46 & $\bigcirc$ 座宗義 & 61.9 & 8 & 19.4 & 13.0 & 18.0 & 15.6 & 18.0 & 84.0 & 9 & 4 \\
\hline 47 & 川 ○善一郎 & 51.9 & 21 & 15.2 & 8.0 & 19.8 & 13.0 & 19.0 & 75.0 & 17 & 8 \\
\hline 48 & ○井宗助 & 59.7 & 14 & 6.0 & 11.0 & 19.0 & 10.0 & 12.0 & 58.0 & 30 & 14 \\
\hline 49 & 村 $\bigcirc$ 義太郎 & 59.5 & 15 & 14.6 & 13.0 & 18.4 & 13.4 & 15.0 & 74.4 & 18 & 27 \\
\hline 52 & ○禎一郎 & 65.9 & 3 & 19.4 & 17.0 & 19.0 & 20.0 & 19.6 & 95.0 & 1 & 6 \\
\hline 53 & 川 $\bigcirc$ 鉦太郎 & 51.9 & 21 & 15.2 & 8.0 & 19.8 & 13.0 & 19.0 & 75.0 & 17 & 7 \\
\hline 54 & $\bigcirc$ 藤 鑛 助 & 51.0 & 22 & 9.2 & 8.0 & 19.0 & 13.2 & 8.0 & 57.4 & 31 & 33 \\
\hline 56 & ○原 繁 藏 & 31.6 & 23 & 13.2 & 10.0 & 17.6 & 10.6 & 8.0 & 59.4 & 26 & 30 \\
\hline
\end{tabular}


601

軍隊に於ける成績序列表

\begin{tabular}{|c|c|c|c|c|c|c|c|c|c|c|c|c|c|c|c|c|}
\hline 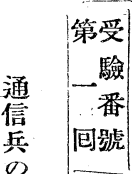 & 代 & 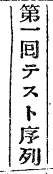 & 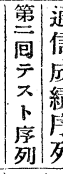 & \begin{tabular}{l|l} 
通 & 中 \\
成 & \\
績 \\
䧘 \\
列
\end{tabular} & 性 & \begin{tabular}{l|l} 
品 & 體 \\
行 & 恪 \\
& 序 \\
列 & 列
\end{tabular} & 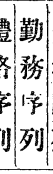 & & & 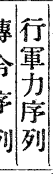 & & & 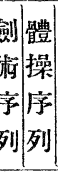 & $\begin{array}{l}\text { 學紏 } \\
\text { 科列 } \\
\text { 序 } \\
\text { 列 }\end{array}$ & & 考 \\
\hline 1 & & & & & & & & & & & & & & & & \\
\hline & 岡p鐵藏 & $\begin{array}{l}16 \\
25\end{array}$ & 6 & 3 & $\begin{array}{lll}1 & 1 \\
1 & \end{array}$ & \begin{tabular}{l|l}
1 & 4 \\
3 & 0
\end{tabular} & \begin{tabular}{ll|}
4 & 1 \\
9 & 0
\end{tabular} & ] & & & 1 & 1 & $\begin{array}{lll}2 & 1\end{array}$ & 1 & 1 . & 上等兵 \\
\hline 2 & $\bigcirc$ ，原 時 & 25 & 151 & 15 & & 32 & $\begin{array}{ll}2 & 3 \\
\end{array}$ & 3 & 3 & \begin{tabular}{l|l|}
3 & 2
\end{tabular} & 3 & 2 & \begin{tabular}{l|l}
3 & 3
\end{tabular} & 2 & 2 & \\
\hline 3 & 井○八作 & 29 & 30 & 32 & 14 & \begin{tabular}{l|l}
4 & 3
\end{tabular} & $\begin{array}{ll}3 & 4 \\
\end{array}$ & 4 & 4 & 2 & 4 & 3 & \begin{tabular}{l|l}
1 & 4
\end{tabular} & 4 & 4 & \\
\hline 4 & ○中紋二郎 & 36 & $\left.28\right|^{\circ}$ & 24 & $1) 2$ & $\begin{array}{ll}2 & 1\end{array}$ & $1 \mid 2$ & 2 & 2 & 1 & 2 & 4 & $\begin{array}{ll}4 & 2\end{array}$ & 3 & 3 & \\
\hline 6 & ○青勇藏 & 23 & 293 & 34 & 23 & \begin{tabular}{l|l}
3 & 4
\end{tabular} & 43 & 3 & 3 & 4 & 3 & 2 & 33 & 3 & $3 \mid 4$ & 敏提 \\
\hline 8 & ○井五郎 & 30 & $\left.21\right|^{2}$ & 29 & 22 & 2 & \begin{tabular}{l|l|}
2 & 2 \\
\end{tabular} & 2 & 2 & 2 & 1 & 3 & $2 \quad 2$ & 2 & 2 & \\
\hline 9 & 菊 ○信一 & 3 & $32: 3$ & 30 & 21 & 1 & 11 & 1 & 1 & 1 & 2 & 4 & 1) 1 & 1 & 1 & \\
\hline 10 & ○田一男 & 35 & 361 & 17 & 4 & 43 & 34 & 4 & $4:$ & & 4 & 1 & \begin{tabular}{l|l|}
4 & 4
\end{tabular} & 4 & $4 \mid$ & 敏提 \\
\hline 12 & ○澤與九郎 & 4 & 16 & 28 & 3 & 3 & 4 4. 4 & 4 & 4 & & 4 & 4 & \begin{tabular}{l|l}
4 & 3
\end{tabular} & 1 & 3 & \\
\hline 13 & 齋 ○光雄 & 9 & $14:$ & $\because 0$ & $3: 2$ & 2 & $\begin{array}{ll}2 & 1\end{array}$ & 1) & 1 & 4 & 3 & 2 & 3.4 & 3 & 2 & \\
\hline 14 & ○伯唇雄 & 17 & 271 & 16 & 34 & 4 & $3: 3$ & 3 & $3:$ & 3 & -1 & 3 & \begin{tabular}{l|l|}
2 & 2
\end{tabular} & 4 & 4 & \\
\hline 15 & 田○文藏 & 18 & 111 & 12 & 1 & 1 & $1 \quad 2$ & 2 & $2:$ & 1 & 1 & 1 & \begin{tabular}{ll|}
1 & 1
\end{tabular} & 2 & 1. & \\
\hline 19 & 淵 ○宗次 & 1 & 3 & 2 & 5 & 1 & $4 \quad 1$ & 1 & 1 & & 1 & 1 & \begin{tabular}{l|l|}
1 & 1
\end{tabular} & 1 . & 1. & 上等兵 \\
\hline 20 & ○辰雄 & 6 & \begin{tabular}{l|l}
8 & 1
\end{tabular} & 19 & 3 & $\begin{array}{ll}3 & 2\end{array}$ & 23 & & $2:$ & 32 & 3 & 4 & \begin{tabular}{l|l|}
3 & 3 \\
\end{tabular} & 3 & 3. & 上等兵 \\
\hline 21 & 町 $\bigcirc$ 竹太郎 & 10 & 5 & 1 & 52 & \begin{tabular}{l|l}
2 & 3
\end{tabular} & 32 & 2 & $4:$ & 21 & 2 & 2 & $\begin{array}{lll}2 & 2\end{array}$ & 2 & 2 & \\
\hline 22 & ○宮定治 & 13 & 102 & $2 \cdot$ & 4 & 4 & 14 & 4 & 34 & & 4 & 3 & $4 \quad 4$ & 4 & 4 & \\
\hline 26 & $\bigcirc$ 部 豐 & 2 & 2 & 5 & 6 & 1 & $4|3|$ & 2 & 2 & & 4 & 2 & 23 & 2 & 3 & 上等兵候補 \\
\hline 27 & 西○捷太郎 & 5 & 72 & 21 & 3 & 3 & \begin{tabular}{l|l}
3 & 2
\end{tabular} & 3 & 31 & 1 & 1 & 1 & 32 & 1 & 2 & 上等兵侯裾制断正確 \\
\hline 28 & ○井富二郎 & 28 & 201 & 11 & $\begin{array}{lll}6 & 1\end{array}$ & 2 & 21 & 1 & 1 & 3 & 2 & 3 & \begin{tabular}{l|l|}
1 & 1
\end{tabular} & 3 & 1 . & 上等兵 \\
\hline 29 & 大 $\bigcirc$ 元 㠶 & 34 & 333 & 35 & 64 & 4 & 1. 4 & 4 & 4 & 4 & 3 & 4 & $4 \quad 4$ & 4 & 4 & \\
\hline 33 & 都○繁太郎 & 7 & 192 & 23 & 1 & 12 & \begin{tabular}{ll|}
2 & 1
\end{tabular} & 1 & 25 & $\begin{array}{lll}2 & 1\end{array}$ & 2 & 1 & 23 & 2 & 2 & \\
\hline 34 & $\bigcirc$ 村政雄 & 12 & 131 & 18 & 3 & 33 & 33 & 3 & $3:$ & $3 \dot{0}$ & 4 & 3 & 34 & 3 & 3 & \\
\hline 35 & 榎○鎭太郎 & 19 & $24 \cdot 2$ & $\begin{array}{ll}25 & 7\end{array}$ & $7 \mid 4$ & \begin{tabular}{l|l}
4 & 4 \\
\end{tabular} & $4 \quad 4$ & 4 & 4 & $4 \quad 4$ & 3 & 4 & $\begin{array}{lll}4 & 2\end{array}$ & 4 & 4 & 总惰テンカン \\
\hline 36 & ○崎幸太郎 & 27 & 222 & 26 & 72 & $\begin{array}{lll}2 & 1\end{array}$ & 12 & 2 & 1. & 2 & 1 & 2 & $1 \quad 1$ & 1 & 1 & \\
\hline 40 & ○林福三郎 & 20 & 12 & 9 & 94 & \begin{tabular}{l|l}
4 & 3
\end{tabular} & $\begin{array}{lll}3 & 3\end{array}$ & 4 & & 22 & 3 & 3 & $\begin{array}{lll}3 & 2\end{array}$ & 1 & 3 & \\
\hline 41 & 飯 $\bigcirc$ 進吉 & 24 & $23 \mid$ & 13 & 1 & 12 & 21 & 3 & 1 & & 1 & 1 & 11 . 1 & 2 & 1 & \\
\hline 42 & $\bigcirc$ 輪昭政 & 26 & $34: 3$ & 36 & 92 & $\begin{array}{lll}3 & 1\end{array}$ & 12 & 1 & : & 1 & 2 & 2 & 23 & 3 & 2 & \\
\hline 43 & 監 $\bigcirc$ 秀雄 & 31 & $25 \mid 1$ & \begin{tabular}{l|l}
10 & 9
\end{tabular} & 9 & 24 & 44 & 2 & 4 & & 4 & 4 & 44 & 4 & & 5月26日兵役免除 \\
\hline 46 & ○坐宗義 & 8 & 9 & 410 & 1 & \begin{tabular}{l|l}
1 & 2
\end{tabular} & 2. 1 & 1 & 2 & & 4 & 4 & \begin{tabular}{ll|}
3 & 4 \\
\end{tabular} & 1 & 2 & \\
\hline 47 & 川○善一郎 & 21 & 17 & 810 & 4 & $\begin{array}{lll}4 & 1\end{array}$ & 14 & 4 & & 1 & 3 & $?$ & 12 & 3 & & 思想上 $\exists$ y外出 \\
\hline 48 & $\bigcirc$ 井宗助 & 14 & 301 & $14 \mid 10$ & 2 & $\begin{array}{ll}2 & 3\end{array}$ & $\begin{array}{ll}3 & 2\end{array}$ & 2 & 1 & 22 & $2 \mid$ & 1 & $\begin{array}{lll}2 & 1\end{array}$ & 2. & & 上等兵 \\
\hline 49 & 村○義太郎 & 15 & 182 & $271 \mathrm{C}$ & 3 & \begin{tabular}{l|l}
3 & 4
\end{tabular} & $4 \quad 3$ & 3 & & & 1 & 3 & & 4 & & 劍術 =カヨ入レル \\
\hline 52 & ○末襀一郎 & 3 & 1 & 611 & 1 & $1 \cdot 2$ & 21 & 1 & & 2 & 3 & 3 & 11. & 1 & 1 & 上等兵 \\
\hline 53 & - 川○鐵太郎 & 21 & 17 & 711 & 2 & 43 & \begin{tabular}{l|l|}
3 & 2
\end{tabular} & & & & 1 & & 22 & & 2 & \\
\hline 54 & $\bigcirc$ 藤 鐄 助 & 22 & 313 & 3311 & 4 & \begin{tabular}{l|l}
3 & 4
\end{tabular} & 44 & & & $\because 4$ & & & 43 & 2 & 4 & \\
\hline 56 & ○原繁藏 & 33 & $|26| 3$ & 3011 & 3 & $\begin{array}{ll}2 & 1\end{array}$ & 13 & -1 & & & & & 34 & 4 & 3 & \\
\hline
\end{tabular}




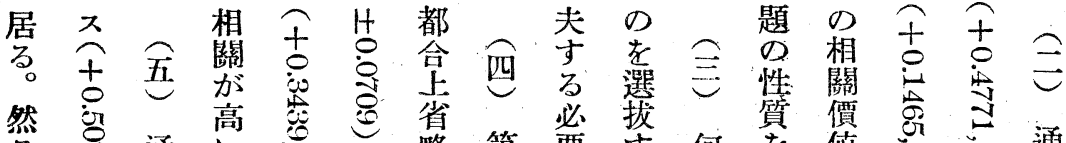
る 过 通然

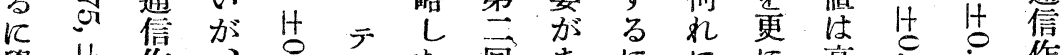

學

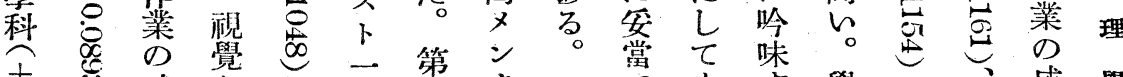

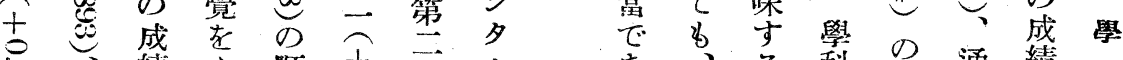

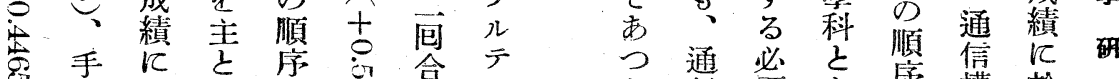

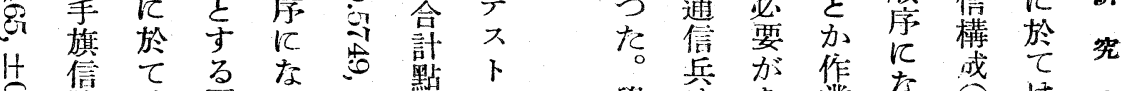

80 號は 圖 己

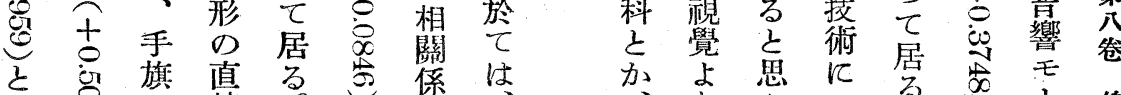

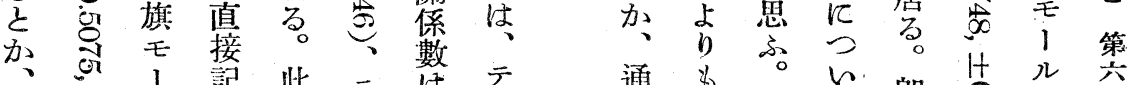

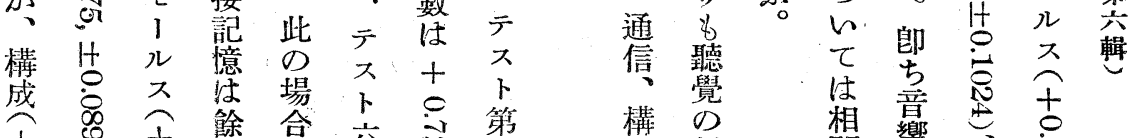

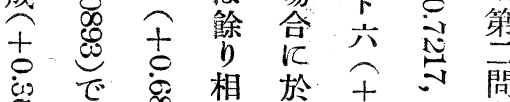

品 た

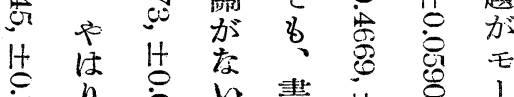

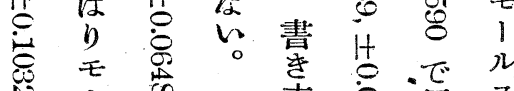

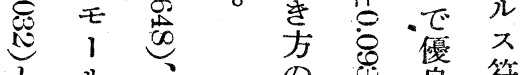

上儿 D

加不音 速

䉓號毛害篦練

話使 1 犼

哭 角

劣績 †

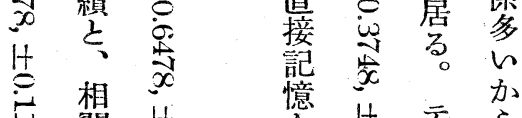

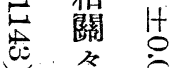

之係恋

加注

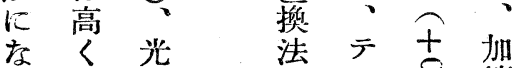

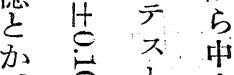

置 点

るな⿻上丨 它算

๖ 1 加 1 步 法

は四边は

構 の

成鋔

技可

術尚

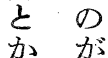

L

云

S. 成

方 縝

面圭

優 L

良て

な居

\& 3

D 從

逼 從

ぶて

に

は

、下

更は

几 疆

問 覺

題 型

起の

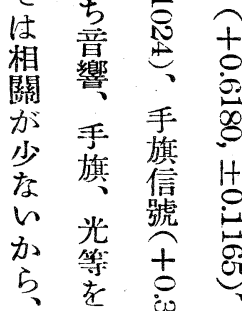

理 .

I 8

此用怘手

の 3 旗

方豆势毛

面

者季學

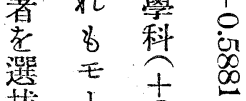

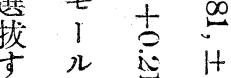

る

は號

使

テ 朋 $\overrightarrow{\text { 光 }}$

ス $の$ E

卜作、1

の栔電 ル

問之話 万 


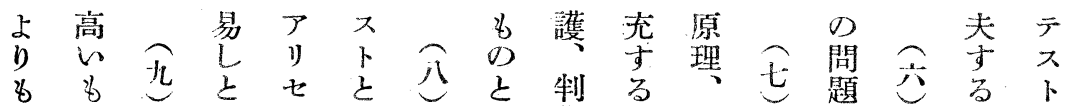

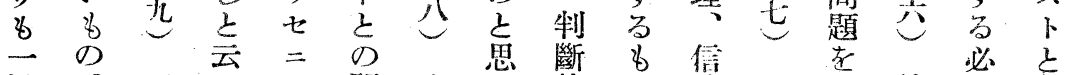

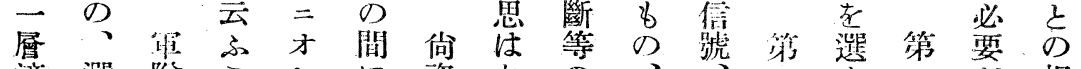

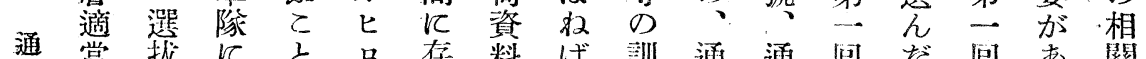

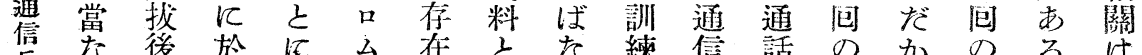
兵な後於に公在と練信話のかかるは

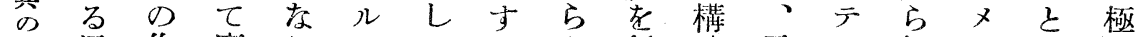
選通作應る

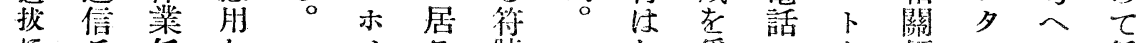
$r$ 兵焦 $L$ 箈基務、礼工。等 施 簡に嘎がレ例 は、

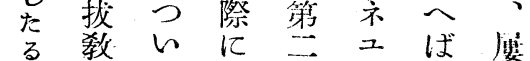

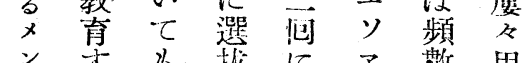

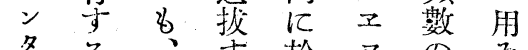

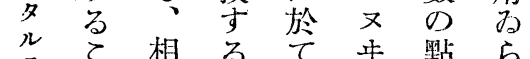

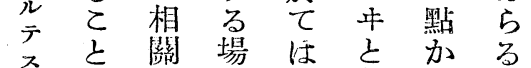

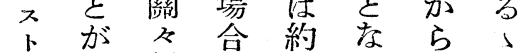
出係饮七去文 垔來多因占て居学

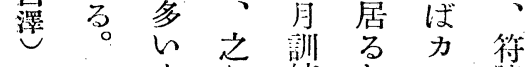
女和練 ᄂ シ 箎 の 等 せ 、イ 構 老方難夕成 背机易ンの

又 件 $\tau$ に ウ 難

卜老居つ易

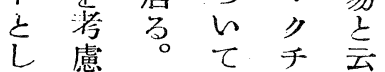

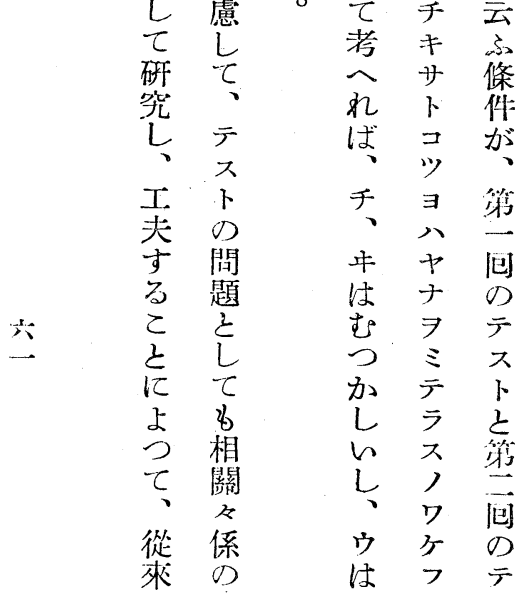

め守 構第 值 テ

当当成光が不

のに问高下佂

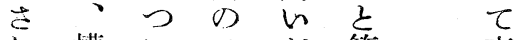

構 い方第來

ば成て ス、沓て

第助教卜テ间居

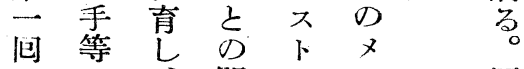

テの、閜のン

ス作總结瓷名

支揮約を を

り敎 官 七 分

は㕕のケへト

第吉任月方文

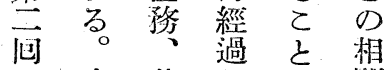

因

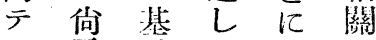

ス 電 點て店は

卜線江居つ+

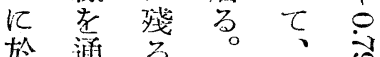

於通方秀

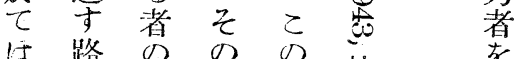

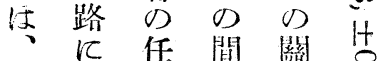

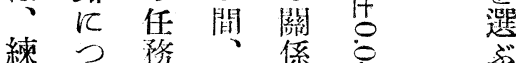

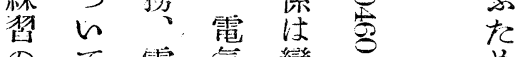

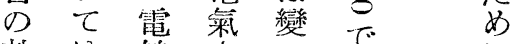

效は線大亏秀、に

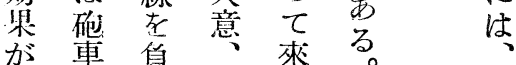

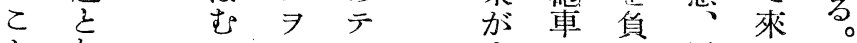

大、方通る比特

分人旅辞跤

抽 馬 の 學 の 的为

は、理之類示

己速電葸似不

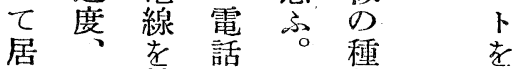

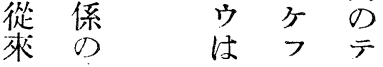

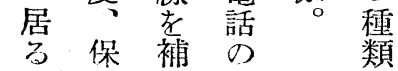

克. 


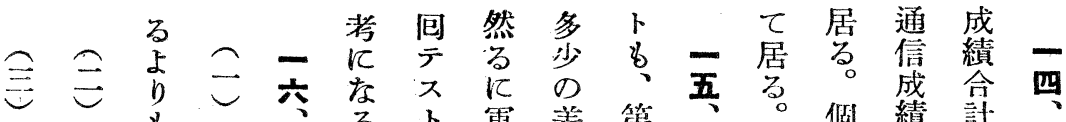
學視時 メ結を庄軍䔬第通と人序點軍

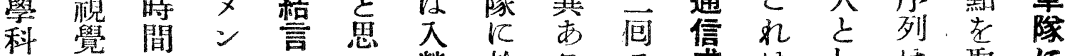

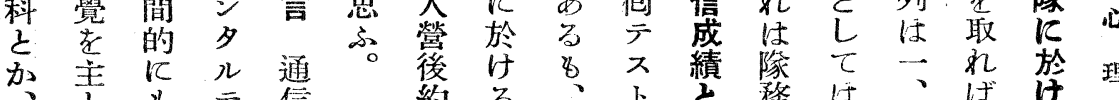

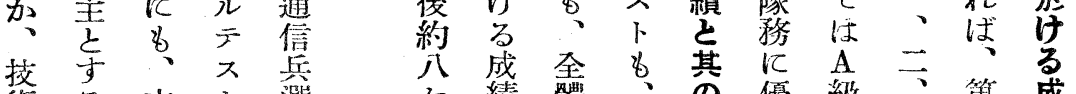

術る方下選 の示法の拔 方不的問比 面下に題 $x$ ○よ \& 老 優 り 簡 通 夕

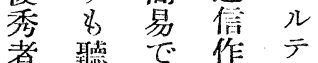

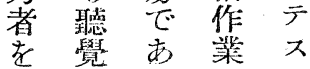
選をる斿 る ぶ主 L 惯 責 に发結祭實 更 る 果 即 L に疗した 特 7 等 殊下兄、績 の の 穙 に 厂方 \&成 スがのす い 下效支れ

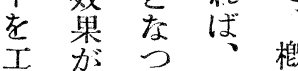
夫多灭榢括

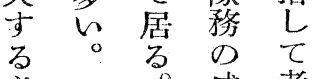
必。成考 要績市 名 市 c i 夰代 其次 の の 他 如

邓 觀 點

點 が

吉市

器亭

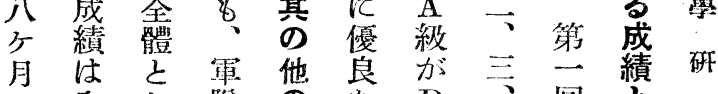

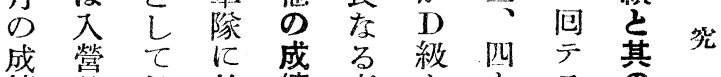

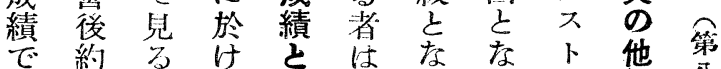

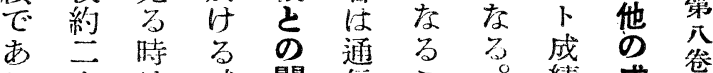

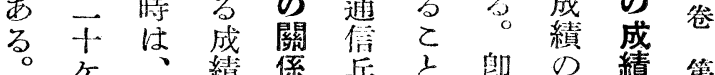

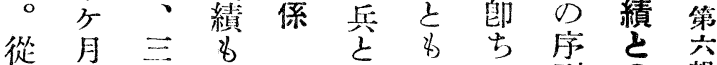

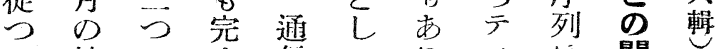

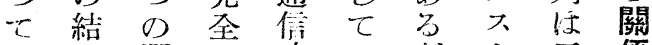
果選企歲名占三俰

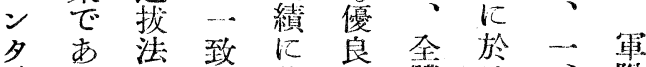

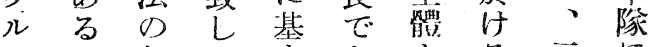

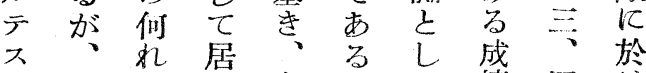
下第妿居各要攵盛四符

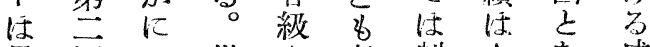
早向上從九瘏制 $\mathrm{A}$ 原成

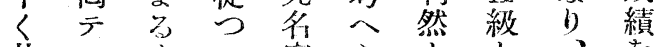

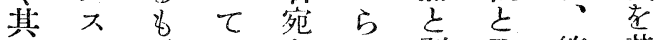

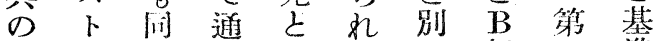

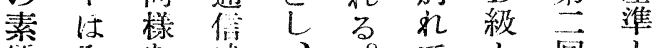

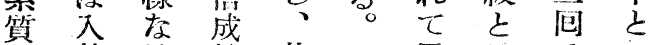

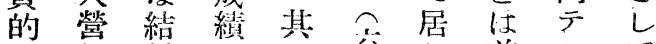

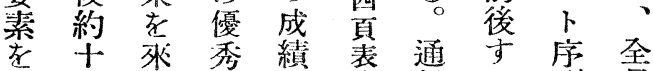

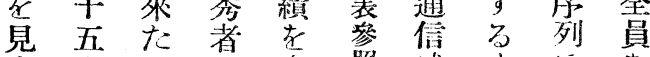

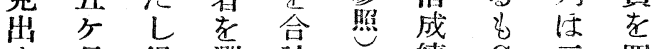
月得遶計綪 $\mathrm{C}$ 四

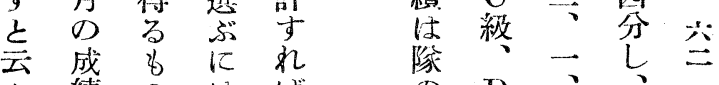
ふ縝の时 點 でを個 西浮人艒

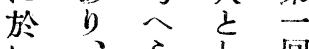

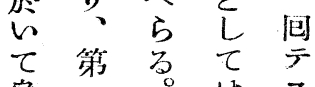
o $\mathrm{D}$

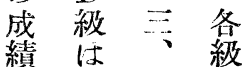
筑。四光 致琵点変 掝

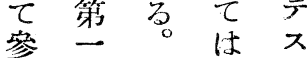
L $\tau$ b 
通信作業とメンタルテストとの相關係數表

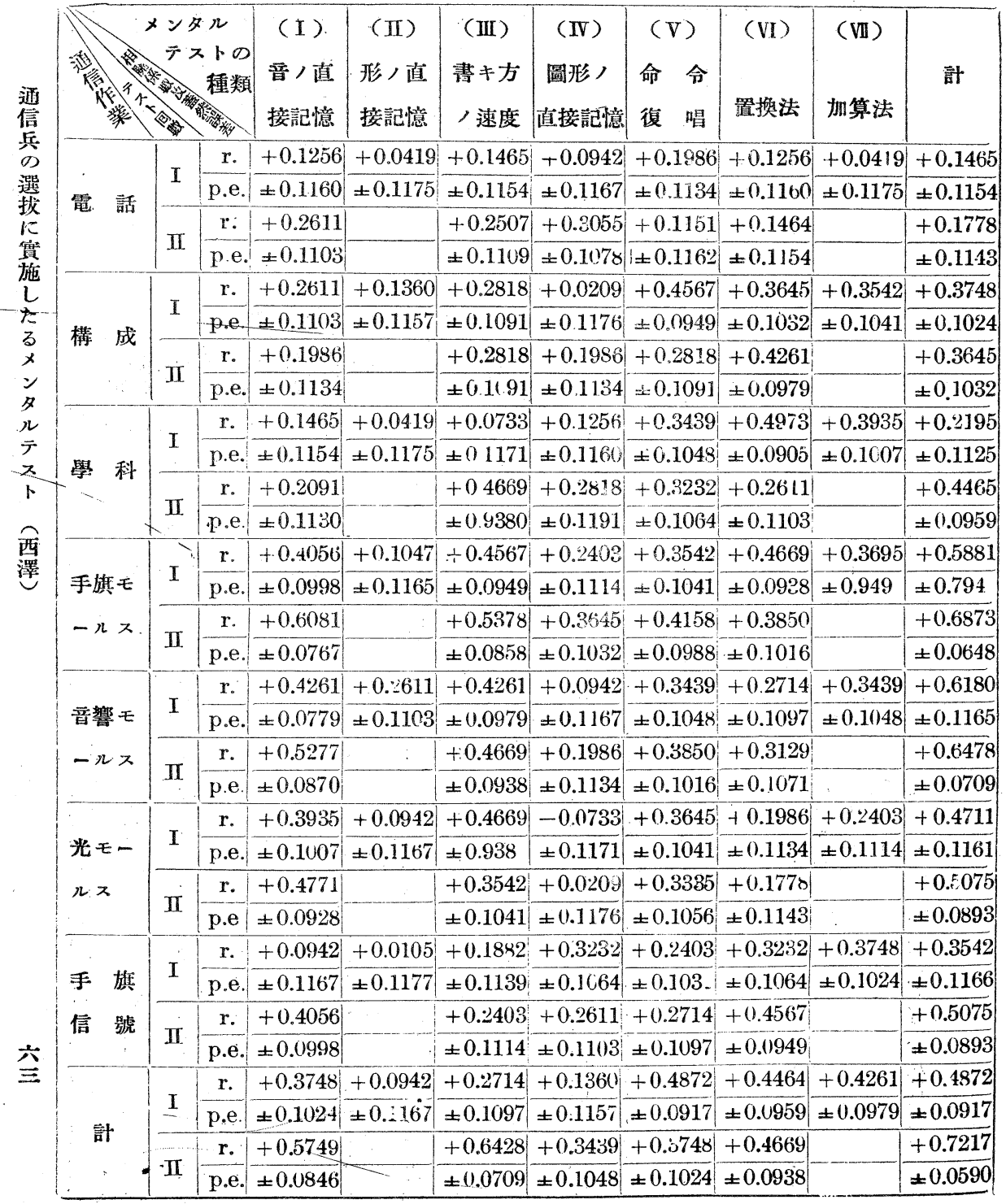




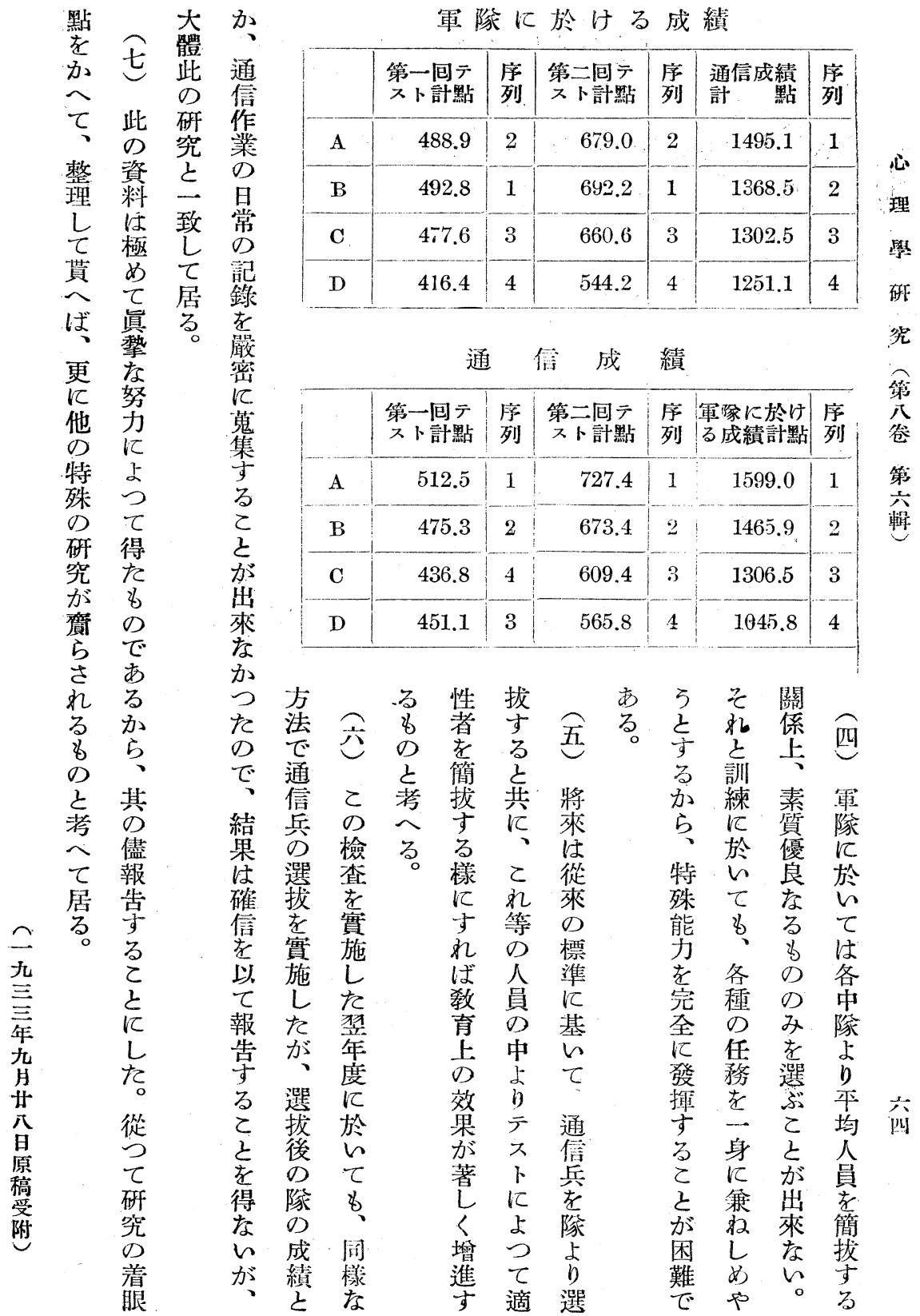




\title{
Mental Tests Applied to the Selection of Reporters
}

\author{
by \\ Raiô Nishizawa \\ The Military Academy
}

These investigations were carried out under the kind advices of the late Dr. Koreshige Masuda.

Subjects were fifty eight Soldiers. Some of them were already recognized as the well-fitted reporters according to the selected method applied up to this time, and the others were selected at ramdom by fives and sevens from each company.

In the first investigation, seven tests were employed. They were as follows :

Test 1. . A test of the direct memory of tones.

Test 2. A test of the direct memory of figures.

Test 3. A test of the the writing speed.

Test 4. A test of the direct memory of simple forms.

Test 5. A test of the repeating of commands.

Test 6. A displacement test.

Test 7. An addition test.

The total sum of full marks of these seven tests is 105. According to the results of tests, the best subject got marks of $\$ 0.3$, and the worst one marks of 6.8 .

Seven months later the second investigation was carried out. In this investigation, the test of the direct memory of forms and the addition test were omitted from the list of tests employed in the first investigation. In this case, therefore, the number of tests is five and the total sum of full marks of five tests is 100 .

Now, if we examine the results according to the coefficients of correlation between the work of communication and the result of tests, we may enumerate the following discoveries:

(1) A coefficient of the total sum of marks is +0.4872 and \pm 0.0917 , and that of test 5 is +0.4872 and \pm 0.0917 , of test $6,+0.4464$ and \pm 0.0959 , of test $7,+0.4261$ and \pm 0.0979 , of test $1,+0.3748$ and \pm 0.1024 , of test $3,+0.2714$ and 
\pm 0.1097 , of test $4,+0.1360$ and \pm 0.1157 , and of test $2,+0.942$ and \pm 0.1167 . Consequently, the test of repeating the command-, the displacement test and the addition test have more relation with the selection of the reporters than the test of direct memory of the figures and forms.

(2) The order of arrangement of the coeflicients with the results of reporting work is the sound morus $(+0.6180), \pm 0.1165)$, the flag morus $(+0.5881$, \pm 0.0794 ), the light morus $(+0.4771, \pm 0.1161$, the composition of communication $(+0.3748, \pm 0.1024)$, the flag signal $(+0.3542, \pm 0.1166)$, the school knowledge $(+0.2195, \pm 0.1125)$ and the telephone $(+0.1465, \pm 0.1154)$. Namely, the correlation of the remorting work is higher with the morus signs of either sound or flag and the like than with knowledge or technique.

(3) In either case, the reporter with more sensibility in the auditory sensation than in the visual shows more satisfactory result. Accordingly, man had better choose the auditory type.

(4) The coefficient of total sum of marks is $+0.7217, \pm 0.0590$. And the test $3(+0.6428, \pm 0.0709)$ comes first. Next the test $1(+0.5794, \pm 0.0846)$, the test $(i)(+0.4669, \pm 0.0938)$, the test $\delta(+0.3748, \pm 0.1024)$ and the test 4 $(+0.3439, \pm 0.1048)$ follow. In this case, too, the correlation is high in the test of the writing speed, the direct memory of tones and the displacement, and low in the test of the direct memory of figures in which the visual sensation plays a principal rôłe.

(5) The coefficients of the communicating work with each test are arranged in order as follows: the flag morus sign $(+0.6873, \pm 0.0648)$, the sound morus sign $(+06478, \pm 0.0709)$, the light morus sign $(+0.5075, \pm 0.0893)$ and the flag signal $(+0.5075, \pm 0.0893)$. We can see here the high correlation with the employment of the morus signs again.

(6) The coefficients of correlation between the result of the first investigation and that of the second are +0.7943 and \pm 0.0460 ; these numbers, of course, will be different according to the kinds of tests.

(7) When the second investigation was began some seven months elapsed since the time the first test was carried out. During these months as the instruction was given on the elemental electricty, the principles of the communication and telephone, and the construction of telegram and telephone etc., we must not forget to take into consideration the practice.

(8) Moreover, we must consider the conditions of the frequency of the employment of letters adopted in the test and of the difficulties of various. 
grades in the sign construction.

(9) In case of applying this result to the practical use, therefore, by means of the tests with high correlation in regard to the problems to be employed and the kinds of works and functions to be studied, we may be able to select the more fitted reporters.

We may summarise the results above mentioned as follows :

( I ) If the problems of the test are selected according to the practical communicating work, the time vill be saved and the method will be simple without changing the result.

(II) In generally, the auditory test is more useful than the visual one.

(III) In order to select the superior respecting the knowledge and technique, the specific tests must be devised.

(IV) We treated our results of these investigations scientifically, but we think possible to treat them in another way which will bring a favourable promise. 